\title{
Obituaries
}

\section{Fritz Klein}

Psychiatrist who pioneered research into bisexuality and who invented a sexual orientation grid

Recognising his attraction to both men and women, in 1974 Dr Fritz Klein tried to research bisexuality at the New York Public Library. He found little information. So he placed an advertisement in The Village Voice, a weekly newspaper in New York's Greenwich Village, asking people interested in bisexuality to meet for discussions.

"I had bisexuals come to my place every week to discuss their own bisexuality as well as bisexuality in general," he told journalist Sheela Lambert of BiMagazine in an interview weeks before his death. "We met weekly for discussion and it quickly turned into a support group. We had about 15-20 people show up every week."

From these discussions Klein developed his Klein Sexual Orientation Grid, which considers a person's sexuality in the past, present, and an idealised future, and published it in the Journal of Homosexuality in 1985. It was based on the Kinsey Scale, which rated sexual orientation on a scale of 0 to 6 , with 0 being exclusively heterosexual and 6 being exclusively homosexual.

However, Klein's grid considered seven variables (sexual attraction, sexual behaviour, sexual fantasies, emotional preference, social preference, self identification, and heterosexual/homosexual lifestyle) and it recognised that the variables might change over time.

The grid "was a culmination of talking to hundreds of bisexuals in the Bisexual Forum in New York where the question of sexual orientation and bisexuality kept coming up. It became obvious after a while that sexual orientation is more complicated than Kinsey's scale," he told BiMagazine. He said that his own place on the grid was bi-gay: closer to the gay side than the heterosexual side, although he had had at least two serious relationships with women.

"Bisexuality is a confusing concept in the general population; this also applies to bisexuals themselves. The grid helps define who they are and where they fit on the sexual orientation continuum," Klein said in an interview with bi.org.au.

Research about bisexuality would help people develop a positive attitude and knowledge about themselves, he said.

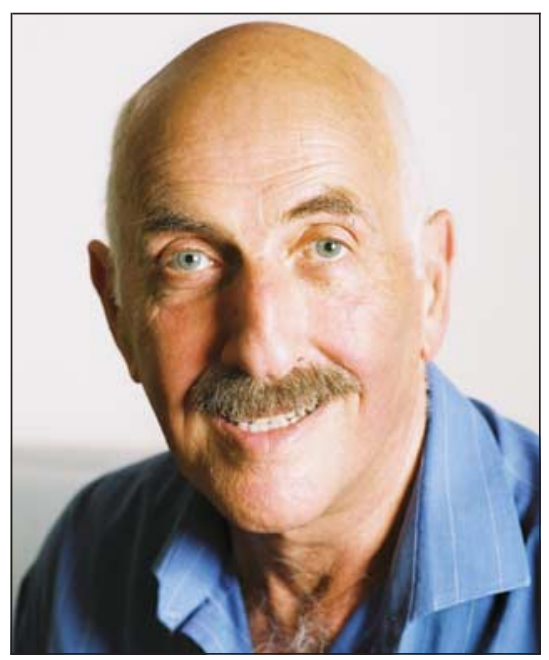

In 1978, he published The Bisexual Option, and later Man, His Body, His Sex, edited bisexual anthologies, founded the Journal of Bisexuality, and published a novel, Life, Sex, and the Pursuit of Happiness.

He founded the Bisexual Forum in New York in 1974 and in 1982 the Bisexual Forum in San Diego, California, where he moved to avoid New York's stress and for better weather and a more relaxed lifestyle. $\mathrm{He}$ also founded the American Institute of Bisexuality (www.bisexual.org) and organised conferences for and about bisexuals.

"He was amazing, courageous, a real pioneer, a very generous, really healthy person, tolerant and bright, who said there was more to people than their sexual selection. He was uncloseted at a time when that was very rare," said sexuality expert Helene Sloan, professor emerita of health and human nutrition at Brooklyn College of the City University of New York. She said that among his contributions was to show that "bisexual" was not the same as homosexual, as many people assumed at the time, and that there was a spectrum of human sexuality.

Fritz Klein was born into an Orthodox Jewish family in Vienna in 1932 and for the first six years of his life he spoke German. Then his family fled Nazi anti-Semitism and settled in New York. He received a bachelor's degree from Yeshiva University in New York in 1953 and an MBA from Columbia University in 1955.

He later realised that he would prefer to study medicine, especially psychiatry. Too old to be accepted at US medical schools, he applied to the University of Bern, brushed up his childhood German, and graduated in 1971. In medical school his emphasis was on sex therapy. He completed a residency in psychiatry at New York Medical College in 1974.

After several years in New York, where he founded the Bisexual Forum, he moved to San Diego and founded the Bisexual Forum there. Klein was also a clinical instructor at the University of California, San Diego.

He travelled widely, loved the theatre, played a few small parts in Lysistrata in Sydney, Australia, and became active in the non-profit Diversionary Theater of San Diego, which presents plays relevant to the lesbian, gay, and transgender community of San Diego and provides a home for San Diego's theatre professionals.

Dan Kirsch, executive director of the theatre, told the $B M J$ that Klein owned the office building in which the theatre is located and was a generous contributor. "He was vivacious, curious about life and people, widely travelled, and he left us a gift in his will as an endowment, the first endowment we've received. It's significant for us."

Klein had been recovering well after surgery for pancreatic cancer but died suddenly from a heart attack at the home he shared with his partner, Tom Reise. According to Klein's wishes, his body was donated to science. Also according to Klein's wishes, Reise said, "plans are being made for a big party in San Diego to celebrate his life." [Janice Hopkins Tanne]

Fritz Klein, founder of the American Institute of Bisexuality (b Vienna, Austria, 1932; q Bern University, Switzerland, 1971), died from a heart attack on 24 May 2006

Longer versions of these obituaries are available on bmj.com 


\section{Bridget ("Biddy") Kathleen Attlee}

Former part time general practitioner Sutton Valence, Kent (b 1921; q St Thomas',London, 1952; SRN, JP), died from lymphoma on 19 February 2006.

Bridget ("Biddy") Kathleen Attlee joined the Nightingale School of Nursing at St Thomas' Hospital in 1940, having previously been a land girl. She qualified as a state registered nurse and worked at St Thomas' until the end of the war. She then became one of the first two woman medical students at St Thomas' Hospital Medical School. Shortly after marrying in 1954, we went to Antigua as district medical officers, resigning and returning to England in December 1954. We then joined a general practice at Sutton Valence in Kent, and Biddy worked as a part time general practitioner and became a JP. She leaves me, four children, and 11 grandchildren. [RICHARd PERKs]

\section{Derek Harvey}

Former general practitioner and specialist in occupational medicine (b 1928; q St Mary's Hospital, London, 1951; OBE), died from heart failure on 31 March 2006.

In 1957 Derek entered general practice in St Columb, Cornwall, leading its expansion into the large modern group that exists today. In 1972 he joined Roan Consolidated Mines in Zambia as a hospital medical officer with a special interest in obstetrics. After six years he was recruited by Shell International Petroleum, being posted in 1979 to Muscat as chief medical officer for Petroleum Development Oman and in 1985 to Brunei as chief medical officer for Brunei Shell Petroleum. On retirement from Shell, he returned to Oman as chief medical officer of Khoula National Trauma Hospital, completing his career in Yemen as medical director of the Joint Oil Companies Clinic in Sana'a. He leaves a wife, Meriel; five children; and three grandchildren. [BILL HARvEY]

\section{John Peter Malone}

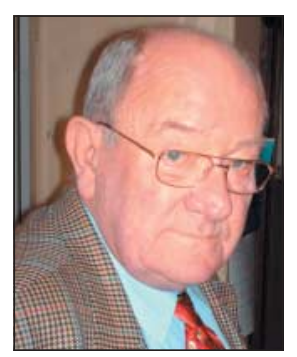

Former general practitioner Hartlepool (b 1933; $q$ Glasgow 1958), died from cancer on 25 March 2006.

John Peter Malone was my father. He came to Hartlepool in 1972 as a general practitioner and found the people of the town most welcoming to him and his family. His wife died after a long illness, and he was left with four young children under 8 to bring up. He worked tirelessly for his family, arranging for housekeepers to live in to take care of us all while he worked long hard hours. In his practice he loved dealing with children, whom he found to be very positive, even in hospital. He retired in 1988 owing to increasing back problems. $\mathrm{He}$ leaves four children and five grandchildren. [Catherine Parry]

\section{Robert (“Bob”) Tennant}

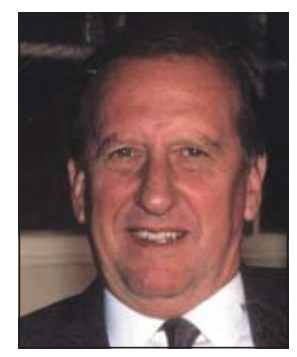

Former general practitioner Highland area (b 1928; q Aberdeen 1951; DCH,DPH), died from parkinsonism and renal failure on 13 February 2006.

Robert ("Bob") Tennant had an interesting and varied career. National service took him to Darjeeling, India, to work with the Gurkhas. After further training in Scotland he spent several years in health programmes in Borneo. His next move was to Libya for two years. He returned to Scotland, working first as a deputy medical officer of health in Inverness and later in Ullapool in general practice. The lure of travel then led him to the Diplomatic Service and several stimulating years as medical officer to the High Commission in Delhi and later the British Embassy in Poland. He finished his professional career as a general practitioner in Fort Augustus. He leaves a wife, Morag; three children; and four grandchildren. [LESLIE BARTLET]

\section{John Luscombe Tester}

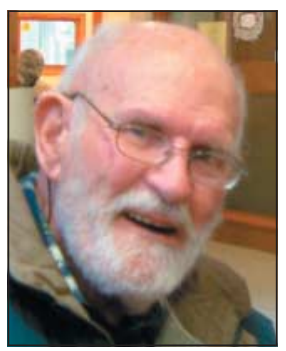

Former medical missionary Nazareth, Israel, and member of the Scottish Health Advisory Board (b 1920; q Royal London Hospital 1950; OBE), died from a ruptured aortic aneurysm on

1 February 2006.

John Tester was a meteorologist stationed in Palestine during the second world war. On his first visit to the Edinburgh Medical Missionary Society's hospital in Nazareth, the medical superintendent thanked him for his help with a patient with the prophetic words: "From now on you are on the staff of this hospital."
After house jobs John returned to Nazareth in 1952, being superintendent from 1957 to 1969. In 1969 he became home director of the Edinburgh Medical Missionary Society but was soon recruited to the newly formed Scottish Health Advisory Board, where he served until retirement. He leaves a wife, Odette; three daughters; and seven grandchildren. [Fred Holmes]

\section{Frederick ("Fred") James Watson}

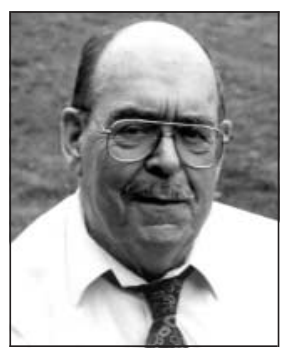

Former general practitioner Wragby and Bardney, Lincolnshire (b 1927; q Queen's University, Belfast, 1978), died from ischaemic colitis on 22 April 2006.

Frederick James Watson ("Fred") had a full and varied life even before he studied medicine at the age of 45. During his $20 \mathrm{~s}$ and $30 \mathrm{~s}$ he developed his artistic talents, excelling particularly as a playwright. In 1962 the Royal Shakespeare Company staged his controversial Infanticide in the House of Fred Ginger at the Arts Theatre in London. Several of his plays were televised. After qualifying Fred worked as a general practitioner at Wragby and Bardney, Lincolnshire, looking after more than 3000 patients single handed for almost 20 years. After retirement and shortly before he died he worked part time for the Cliff House practice in Lincoln. He leaves a wife, Sheila, and three children. [Agnes Watson]

\section{Henry Thomas ("Tom") Gee Williams}

Former professor and chairman Clinical Surgery Department, University of Alberta, Canada (b 1925; q Liverpool 1948; FRCS, FRCS (C), FACS), d 24 March 2006. In 1956 after surgical training in Liverpool Henry Thomas ("Tom") Williams went to Edmonton, Alberta, on a research fellowship. In 1957 he was offered the post of clinical lecturer, which led to appointment as professor and chairman of the Department of Surgery at the University of Alberta in 1975 . He retired as chairman in 1986 and as professor of clinical surgery in 1990. As consultant surgeon he attended the University of Alberta Hospital, two hospitals in Edmonton, and the Seton Memorial Hospital in Jasper, 250 miles away. He was a founder member of the Association of General Surgeons of Canada in 1971, being secretary and archivist from 1971 to 1986 and president in 1986. He leaves a wife, Betty, and four children. [EDGAR W PARRY] 